\title{
NAMIESTNICY KRÓLESTWA POLSKIEGO WOBEC POLSKIEGO RUCHU NIEPODLEGŁOŚCIOWEGO W DRUGIEJ POŁOWIE 1861 I PIERWSZEJ POŁOWIE 1862 ROKU W ŚWIETLE ICH KORESPONDENCJI Z CAREM ALEKSANDREM II
}

\begin{abstract}
NAMIESTNIKS OF THE KINGDOM OF POLAND AND THEIR ATTITUDE TOWARDS THE INDEPENDENCE MOVEMENT

IN THE SECOND HALF OF 1861 AND THE FIRST HALF OF 1862

IN THEIR CORRESPONDENCE WITH THE TSAR ALEXANDER II

The 1861 events proved to be essential for the development of independence movement in the Kingdom of Poland. The growing revolutionary feelings were further roused by the incompetent policy of the Tsar and his namiestniks (viceroys in Poland), whose decisions resulted in the orderly rule of the kingdom becoming increasingly difficult. The namiestniks had to meet Tsar's demands, while at the same time trying at ameliorate the worsening domestic situation. The Tsar had obvious difficulty with the selection of appropriate personae to execute these functions. Namiestniks were changed four times in the span of one year, and the post was held by Mikhail Dmitrievich Gorchakov, Nikolai Onufrievich Sukhozanet, Karl Karlovich Lambert and Alexander Nikolajewitsch von Lüders. Keeping order and strict military regulations was not accompanied by knowledgeable execution of civilian administration, which would respect the specific situation of the Kingdom of
\end{abstract} Poland.

Keywords: namiestnik (Viceroy of the Kingdom of Poland), Kingdom of Poland, independence movement, insurrection

Słowa kluczowe: namiestnik, Królestwo Polskie, ruch niepodległościowy, powstanie 
Po 25 latach nieprzerwanych rządów w Królestwie Polskim księcia Iwana Paskiewicza nastąpiło wyraźne załamanie ciągłości sprawowania urzędu namiestnika. Przypadło to na okres przedpowstaniowy, kiedy destabilizacja czynników społeczno-politycznych wymagała od zarządców Królestwa Polskiego szczególnych umiejętności taktycznych w interakcjach z manifestantami, jak również w kontaktach z carem. Oczekiwał on bowiem natychmiastowego rozprawienia się z przywódcami rozruchów, nie znając przy tym realiów, jakie panowały w Warszawie. Wynikało to między innymi ze świadomego nieinformowania władcy o zajściach w Królestwie lub pomniejszania ich znaczenia ${ }^{1}$. Obawiając się utraty stanowiska i popadnięcia w niełaskę, namiestnicy balansowali pomiędzy koniecznościami wykonywania poleceń cara a zapobiegania rewolucyjnym nastrojom tłumów, których ze względu na ich nieprzewidywalność nie dało się kontrolować i skutecznie stłumić, pomimo zabiegów pozornie łagodzących sytuację.

Po śmierci księcia I. Paskiewicza i przejęciu obowiązków od Wincentego Krasińskiego stanowisko namiestnika w 1856 r. otrzymał książę Michaił Gorczakow. Urodził się on prawdopodobnie w 1792 r. $^{2}$ w niezamożnej, szlacheckiej rodzinie, której korzenie sięgały rodu Rurykowiczów. Gorczakowie od wielu pokoleń związani byli z armią, w której poszukiwali środków utrzymania oraz poczucia prestiżu. Bogatą tradycję wojskową musiał także kontynuować Michaił, którego kariera rozpoczęła się niezwykle wcześnie, bo w wieku 15 lat, gdy w 1807 r. zaciągną się jako junkier do artylerii gwardyjskiej, awansując jeszcze w tym samym roku na stopień oficerski³ Jego ojciec, oprócz odpowiedniego wyszkolenia wojskowego, zadbał także o wykształcenie humanistyczne swoich dzieci, dzięki czemu oprócz języka ojczystego Michaił znał także francuski oraz niemiecki. To też miało sprawić, że odstawał od większości rosyjskich żołnierzy, nie pojmując przy tym także uprawiania sztuki wojennej. Nie posiadał on cech dobrego dowódcy, dlatego jego wyprawy wojenne kończyły się porażką. Już ze stopniem generała adiutanta i na stanowisku szefa sztabu Pierwszego Korpusu Piechoty brał udział w thumieniu powstania z $1831 \mathrm{r}^{4}{ }^{4}$ Wtedy też został zauważony przez Iwana Paskiewicza, który poszukiwał szefa sztabu armii czynnej. Według namiestnika M. Gorczakow idealnie pasował do tej roli z uwagi na

$1 \quad$ Korespondencja namiestników Królestwa Polskiego z 1861 roku, red. S. Ki en i e w ic z, I. M ille r, WrocławWarszawa-Kraków 1964, s. 9.

2 [W. Przyborowski], Historia dwóch lat 1861-1862, Część wstępna. 1856-1860, t. 1, Kraków 1892, s. 55; M. B erg, Zapiski o powstaniu polskim 1863 i 1864 i poprzedzajacej powstanie epoce demonstracji od 1856 r., t. 1, Kraków 1898, s. 30; D.N. Sziłow, Gosudarstwjennyje dejatjeti rossijskoj imperii. Gtawy wysszich i cjentralnych uczrieżdjenij 1802-1917, Sankt Petersburg 2001, s. 188; por. z: Korespondencja namiestników Królestwa Polskiego z 1861 roku, s. 330; Enciktopedija wojennych i morskich nauk, t. 2, red. gen. Li i jer, Sankt Petersburg 1885, s. 555.

3 M. B r rg, Zapiski o powstaniu..., t. 1, s. 30 - autor wskazuje tam na złą sytuację finansową Michaiła, który musiał dzielić się butami paradnymi ze swoim bratem Piotrem.

4 S. Orgelbrand, Encyklopedia powszechna zilustracjami i mapami, t. 4: Od litery G do Herburty, Warszawa 1900, s. 232. 
reprezentowane cechy charakteru, a przede wszystkim ze względu na swoje niezdecydowanie oraz problem $z$ samodzielnym podejmowaniem decyzji. Feldmarszałek potrzebował człowieka uległego, który nie był w stanie pokrzyżować mu planów, przy jednoczesnym założeniu, że Gorczakow nie nadawał się do zajmowania tak odpowiedzialnego stanowiskas Namiestnik twierdził, że w razie konieczności będzie mógł w każdej chwili zareagować i skorygować niewłaściwe decyzje roztargnionego księcia. M. Gorczakow w 1843 r. awansował, zostając generałem artylerii, a trzy lata później otrzymał nominację na stanowisko wojennego generała-gubernatora warszawskiego ${ }^{6}$, sprawując władzę nad wojskiem, policją oraz administracją cywilną. Kolejne lata to również czynna działalność wojskowa M. Gorczakowa, przede wszystkim w wojnie krymskiej w latach 1854-1856, na froncie naddunajskim. Z polecenia I. Paskiewicza objął on dowództwo nad armią południową po księciu Aleksandrze Mienszykowie, którego zdymisjonowano ze względu na ponoszone klęski . Mimo złej passy M. Gorczakowa dano mu kolejną szansę wykazania się, tym razem z dala od pól bitewnych, ale również w trudnych warunkach. Objął on stanowisko namiestnika Królestwa Polskiego po zmartym 1 lutego 1856 r. feldmarszałku I. Paskiewiczu. Ten przez ponad 20 lat wytykał ułomności swojego protegowanego, uważając go przy tym za „zero”, jednak za lojalność wobec siebie chętnie nagradzał awansami'. Ta trudna służba u boku I. Paskiewicza miała się odcisnąć piętnem na psychice księcia, który w dodatku zaczął niedowidzieć i niedosłyszeć, co sprawiało, że momentami żył w oderwaniu od rzeczywistości

$5 \quad$ M. Berg, Zapiski o powstaniu..., t. 1, s. 35-36 - wskazano tam na epizod potwierdzający nieudolność Gorczakowa w dowodzeniu armią. W 1842 r. Iwan Paskiewicz zorganizował wojenną grę planszową, w której odgrywał rolę atakującego, a obroną miał kierować M. Gorczakow. Gra polegała na przesuwaniu po planszy swojego rodzaju pionków symbolizujących odpowiednie oddziały wojskowe. Ruchy wykonywano podczas nieobecności przeciwnika, który na chwilę opuszczał pokój, a następnie pionki przykrywano papierem. W trakcie jednej z rozgrywek pomocnik M. Gorczakowa zasugerował mu inne ułożenie pionków. Generał w swoim niezdecydowaniu dwukrotnie zmieniał ustawienie, wypraszając I. Paskiewicza z gabinetu, co go rozzłościło. Naśmiewający się z M. Gorczakowa generał Fiodor Berg doprowadził do sytuacji, że ten się obrazil, a grę musiano przerwać.

6 F. Ramotowsk a, Zarząd Wojennego Generat-Gubernatora Warszawskiego, [w:] Archiwum Gtówne Akt Dawnych w Warszawie. Przewodnik po zasobie, red. ead e m, t. 2: Epoka porozbiorowa, Warszawa 1998, s. 427; por. z: S. Orgelbrand, op. cit., s. 232, gdzie wspomniano o urzędzie wojennego gubernatora warszawskiego. Franciszka Ramotowska wykazała, że został on przemianowany rozkazem carskim z dnia 26/28 maja 1846 r. na wojennego generała-gubernatora warszawskiego wskutek rozszerzenia jego kompetencji oraz nominacji na to stanowisko generała M. Gorczakowa.

7 M. B erg, Zapiski o powstaniu..., t. 1, s. 42 - autor podaje tam, że feldmarszałek I. Paskiewicz miał żałować rekomendacji M. Gorczakowa na stanowisko dowódcy armii: „Wyznaję, żem zawinił wobec ojczyzny, pomagając do wyniesienia was, książę, na stanowisko, które obecnie zajmujecie”.

8 Ibidem, s. 37, 40 - autor cytuje słowa I. Paskiewicza wypowiedziane o M. Gorczakowie: „Co mi to za pomocnik, to pionek, to zero!".

9 Ibidem, s. 37, 42; [autor nieznany], Przed powstaniem styczniowym. Rozprawa w Kole literacko-artystycznym we Lwowie nad ksiązką „Historia dwóch lat 1861-1862” przez Z.L.S., Lwów 1894, s. 55 - autor określa tam M. Gorczakowa mianem „niedołężnego zera, bez woli i energii, drzemiącego jedynie na krześle kurulnym i czytającego romanse francuskie”. 
Początek jego urzędowania zbiegł się z wizytą cara Aleksandra II w Warszawie. Car podczas spotkania z przedstawicielami szlachty 27 maja 1856 r. zapowiedział szereg reform w Królestwie Polskim, stwierdzając jednocześnie, że Polacy powinni wyzbyć się marzeń o niepodległości. Wcześniej myśl tę miał podsunąć carowi właśnie książę M. Gorczakow ${ }^{10}$.

Prowadzona przez niego polityka w stosunku do Polaków nie przyniosła oczekiwanego efektu. Polacy zaczęli bowiem toczyć ożywione debaty polityczne o przyszłości kraju oraz o znaczeniu słów cara - słów wypowiedzianych do nich w 1856 r. Nieustannie narastały nastroje rewolucyjne, potęgowane silnym oddziaływaniem kleru na warszawską społeczność. O ile pierwotnie ruchy spiskowe prowadziły raczej niegroźną agitację, ignorowaną przez M. Gorczakowa ${ }^{11}$, o tyle bieg wydarzeń przyspieszył w 1861 r. w związku z dużymi manifestacjami przeprowadzonymi na ulicach Warszawy 13 (25) oraz 15 (27) lutego, które to manifestacje zakończyły się pięcioma ofiarami śmiertelnymi po stronie manifestantów ${ }^{12}$. Tego samego dnia, którego doszło do śmierci protestujących, w pałacu namiestnika pojawiła się tzw. Delegacja Miejska wraz z przedstawicielami Towarzystwa Rolniczego członkowie w sposób bezpośredni wyrazili swoje rozgoryczenie i przedstawili namiestnikowi listę żądań ${ }^{13}$. Gorczakow ugią się w końcu, zgadzając się na spełnienie wszystkich postulatów. Jednym z nich było zwolnienie ze stanowiska oberpolicmajstra warszawskiego Fiodora Trepowa ${ }^{14}$, za którego zawieszenie namiestnik dostał naganę od cara ${ }^{15}$. Pokazuje to, że książę podlegał niezwykle silnej presji nie tylko ze strony Polaków, ale także bliskich doradców i samego imperatora, który odmawiał zgody na jakiekolwiek ustępstwa ${ }^{16}$.

10 M. Berg, Zapiski o powstaniu..., t. 1, s. 51; [autor nieznany], Przed powstaniem..., s. 15-16; S - n B i [sygn. nierozwiązana], Zastugi Aleksandra II, „Gazeta Narodowa” (Lwów), 23 III 1881, s. 2 - zacytowano tam słowa cara wypowiedziane do przedstawicieli szlachty: „Żadnych marzeń! Będę nielitościwie srogim i potrafię być srogim". Autor rozprawy Przed powstaniem... zauważył, że car wypowiedział się w podobnym tonie już $23 \mathrm{~V} 1856$ r., gdy przyjmował reprezentantów duchowieństwa, szlachty oraz urzędników.

11 Michat Gorczakow do Aleksandra II, Warszawa, 5 (17) II 1861, [w:] Korespondencja namiestników Królestwa Polskiego z 1861 roku, s. 4-5.

12 H.L is icki, Aleksander Wielopolski 1803-1877, t. 1, Kraków 1878, s. 143; Michat Gorczakow do Aleksandra II, Warszawa 14 (26) II 1861, [w:] Korespondencja namiestników Królestwa Polskiego z 1861 roku, s. 5; Michat Gorczakow do Aleksandra II, Warszawa, 16 (28) II 1861, [w:] Korespondencja namiestników Królestwa Polskiego z 1861 roku, s. 5-6.

13 M. Berg, Zapiski o powstaniu..., t. 1, s. 154-156; H. Lisicki, op. cit., t. 1, s. 144. Autorzy tych pozycji podają relację fotografa Karola Beyera: „[...] byliśmy niesłychanie rozdrażnieni; nie wiedzieliśmy o tym, że to właśnie największy efekt zrobiło. Audiencja trwała z godzinę, i wszyscy razem lub pojedynczo ucieraliśmy się jak mogli, nic w bawełnę nie obwijając. [...] dopiero później poświęcono nam Tropowa i tak dalej, i tak dalej".

14 [J. Stella-Sawicki], Ludzie i wypadki z 1861-1865 r. Obrazki z powstania, Lwów 1894, s. 41.

15 Aleksander II do Michata Gorczakowa, Petersburg, 16 (28) II 1861, godz. 14:50, [w:] Korespondencja namiestników Królestwa Polskiego z 1861 roku, s. 7.

16 Aleksander II do Michata Gorczakowa, Petersburg, 16 (28) II 1861, godz. 16:50, [w:] Korespondencja namiestników Królestwa Polskiego z 1861 roku, s. 10. 
Gorczakow w listach do władcy tłumaczył się z podjętych kroków jako środków zapobiegawczych przed wybuchem powstania. Przeraził się, że odrzucenie żądań Polaków doprowadziłoby do utraty kontroli nad miastem, wycofania wojska do Cytadeli, a w końcu do zbombardowania Warszawy ${ }^{17}$. Namiestnik w obawie przed zaostrzeniem sytuacji w Królestwie 2 marca posłał do Sankt Petersburga Jana Karnickiego, sekretarza stanu przy Radzie Administracyjnej, z poleceniem zdania relacji z wydarzeń w Warszawie oraz z propozycją wprowadzenia w Królestwie szerszych reform ${ }^{18}$. Jeszcze przed przybyciem J. Karnickiego do cara ten ostatni w telegramie do M. Gorczakowa z 21 lutego (5 marca) 1861 r. nakazał rozbrojenie ludności Królestwa, a w razie konieczności ostrzelanie Warszawy ${ }^{19}$.

Ocenia się, że na początku 1861 r. w Warszawie stacjonowało około 10,6 tys. żołnierzy, a po wydarzeniach lutowych nastąpił wzrost ich liczebności do 15 tys. Nastawiano się jednak na obronę i utrzymanie połączeń z Cesarstwem niż na kontratak z powodu oczywistych trudności w przerzuceniu oddziałów z prowincji, gdzie te były niezbędne $e^{20}$. Wydarzenia w Królestwie znalazły swój oddźwięk także w Cesarstwie, wzbudzając ciekawość tamtejszych działaczy politycznych. Z jednej strony pojawiały się emocje negatywne, jak strach przed nagłą zmianą polityki wewnętrznej rządu oraz zagrożeniem dla procesu reform, a z drugiej okazywano wręcz podziw dla ruchu rewolucyjnego ${ }^{21}$.

Tymczasem namiestnik w porozumieniu z margrabią Aleksandrem Wielopolskim dosłał do Petersburga projekt ukazu o reformach autorstwa tego ostatniego. Projekt ten trafił pod obrady Rady Ministrów 13 marca 1861 r., a już 21 marca (2 kwietnia) treść aktu obwieszczono opinii publicznej ${ }^{22}$. W okresie oczekiwania na ukaz M. Gorczakow, widzący wzrost aktywności ruchów rewolucyjnych, prosił o wskazanie dokładnej daty przyjazdu J. Karnickiego ${ }^{23}$. Prawdopodobnie w celu uspokojenia namiestnika car telegrafowal 14 (26) marca, że popiera nominację A. Wielopolskiego na stanowisko dyrektora głównego Komisji

17 Michat Gorczakow do Aleksandra II, Warszawa, 17 II (1 III) 1861, [w:] Korespondencja namiestników Królestwa Polskiego z 1861 roku, s. 12.

18 D. Szpoper, Aleksander Wielopolski i próba ustrojowej rekonstrukcji Królestwa Polskiego w latach 1861 -1862, [w:] Próba ustrojowej rekonstrukcji Królestwa Polskiego w latach 1861-1862. W 150. rocznicę reform margrabiego Aleksandra Wielopolskiego, red. L. Mażewski, Olsztyn 2012, s. 11; H. Lisicki, op. cit., t. 1, s. 144; [J. Stella-Sawicki], op. cit., s. 52.

19 Aleksander II do Michata Gorczakowa, Petersburg, 21 II (5 III) 1861, [w:] Korespondencja namiestników Królestwa Polskiego z 1861 roku, s. 23.

20 K. Gron iow ski, Dowództwo rosyjskie wobec manifestacji warszawskich 1861 roku, „Przegląd Historyczny” 1961, t. 52, s. 726, 737-738.

${ }^{21}$ H. Głębocki, Fatalna sprawa. Kwestia polska w rosyjskiej myśli politycznej (1856-1866), Kraków 2000, s. 150 .

22 D. Szpoper, Aleksander Wielopolski.., s. 15-19, gdzie szerzej opisano prace nad projektem reform.

23 Michat Gorczakow do Aleksandra II, Warszawa, 13 (25) III 1861, [w:] Korespondencja namiestników Królestwa Polskiego z 1861 roku, s. 73. 
Rządowej Wyznań i Oświecenia Publicznego oraz Leona Gieczewicza na dyrektora Komisji Rządowej Spraw Wewnętrznych ${ }^{24}$. Książę M. Gorczakow meldował ministrowi wojny Mikołajowi Suchozanetowi o pozytywnych reakcjach społeczeństwa na zapowiedziane reformy i nominacje $\mathrm{e}^{25}$, co okazało się przedwczesnym wyrazem optymizmu. Namiestnik nie mógł już opanować ruchów narodowych, które z każdą kolejną manifestacją przybierały na sile, poczynając od dnia pogrzebu pięciu poległych w zajściu z 27 lutego, który odbył się 2 marca 1861 r. Sytuację w mieście zaostrzyła likwidacja Delegacji Miejskiej oraz Towarzystwa Rolniczego 6 kwietnia $^{26}$, na co społeczność zareagowała kolejnymi rozruchami ${ }^{27}$. Dnia 7 kwietnia 1861 r. Polacy zebrali się między innymi przed zamkiem namiestnikowskim. Gorczakow spełnił wcześniej daną obietnicę i podpierając się laską, wyszedł do demonstrantów, krzycząc, aby ci się rozeszli, jednak tłum zareagował śmiechem i wyzwiskami, zmuszając namiestnika do wycofania się za kordon żołnierzy ${ }^{28}$.

Gorczakow zwlekał z podjęciem decyzji o rozwiązaniu polskich organizacji ${ }^{29} \mathrm{w}$ sytuacji, gdy odpowiedni nakaz cara dotarł do niego już 18 marca $^{30}$. W celu ograniczenia demonstracji powzięto decyzję - z inicjatywy A. Wielopolskiego - o uchwaleniu tzw. „ustawy o zbiegowiskach", którą ogłoszono 8 kwietnia. Przyniosła ona jednak odwrotny efekt do zamierzonego, przyczyniając się do krwawych starć na ulicach Warszawy. Car Aleksander II oraz minister spraw zagranicznych, Aleksander Gorczakow co jakiś czas krytykowali namiestnika za prowadzenie polityki ustępliwości, nakazując stosowanie bardziej radykalnych środków ${ }^{31}$. W odpowiedzi książę M. Gorczakow wysłał telegram do ministra spraw zagranicznych z dramatycznym opisem swojego położenia, w którym to telegramie oznajmił, że otoczony jest zdradą, wskazując także na "głupotę współpracowników”32. Towarzyszące mu przez ostatnie dni napięcie doprowadziło do znacznego pogorszenia stanu zdrowia nie

24 Aleksander II do Michata Gorczakowa, Petersburg, 14 (26) III 1861, [w:] Korespondencja namiestników Królestwa Polskiego z 1861 roku, s. 75.

25 Michat Gorczakow do Mikotaja Suchozaneta, Warszawa, 18 (30) III 1861, [w:] Korespondencja namiestników Królestwa Polskiego z 1861 roku, s. 82.

26 [J.Stella-Sawicki], op. cit., s. 43.

27 [W. Przyborowski], Historia dwóch..., cz. I: Rok 1861, t. 2: Styczeń - Maj, Kraków 1893, s. 138-139.

28 M. B erg, Zapiski o powstaniu..., t. 1, s. 269.

29 J.K. Ja n ow ski, Pamiętniki o powstaniu styczniowym, t. 3: Czasy przedpowstaniowe 1854-1862, Warszawa 1931, s. 224-225.

30 Aleksander II do Michata Gorczakowa, Petersburg, 6 (18) III 1861, [w:] Korespondencja namiestników Królestwa Polskiego z 1861 roku, s. 56.

31 Aleksander II do Michata Gorczakowa, Petersburg, 8 (20) III 1861, [w:] Korespondencja namiestników Królestwa Polskiego z 1861 roku, s. 59; Aleksander Gorczakow do Michata Gorczakowa, Petersburg, 28 III (9 IV) 1861, [w:] Korespondencja namiestników Królestwa Polskiego z 1861 roku, s. 108.

32 Michat Gorczakow do Aleksandra Gorczakowa, Warszawa, 29 III (10 IV) 1861, [w:] Korespondencja namiestników Królestwa Polskiego z 1861 roku, s. 112. 
tylko fizycznego, ale również psychicznego ${ }^{33}$, zmuszając go do przeprowadzenia się na jakiś czas do Belwederu. O chorobie poinformował Mikołaja Suchozaneta w telegramie z 19 kwietnia $1861 \mathrm{r}^{34}$, a car wydał zgodę na opuszczenie Królestwa w celu rekonwalescencji3 ${ }^{35}$. W akcie zadośćuczynienia carowi za dotychczasową politykę wewnętrzną zdecydował się na utworzenie w mieście czterech okręgów wojennych na czele z naczelnikami wojenny$\mathrm{mi}^{36}$. Był to kolejny zabieg zastosowany, by uniknąć ogłoszenia stanu oblężenia, na co car wyrażał aprobatę w razie pojawienia się kolejnych manifestacji.

Stan zdrowia namiestnika pogarszał się z dnia na dzień, co spowodowało, że zdecydowano się na sprowadzenie do Warszawy jego żony oraz dwóch córek. Generał Mikołaj Kryżanowski poinformował Petersburg o stanie M. Gorczakowa w telegramie z 25 maja, pisząc, że „lekarze mówili, że nie ma zagrożenia dla jego zdrowia" ${ }^{\text {"37 }}$, jednak ten nie był w stanie wykonywać swoich obowiązków. W efekcie odsunięto namiestnika od pełnienia dotychczasowych funkcji, powierzając je M. Kryżanowskiemu oraz generałowi Zygmuntowi Marchelewiczowi, który do tej pory sprawował urząd wojennego generała-gubernatora Warszawy ${ }^{38}$. Pierwszy z nich objął dowództwo nad armią, a drugi zastąpił namiestnika w Radzie Administracyjnej ${ }^{39}$. Ostatnią propozycją M. Gorczakowa było sprowadzenie do Warszawy Michała Murawiewa, zwanego później „Wieszatielem”0, jako jego następcy, jednak do takiego powołania nie doszło, zdecydowano się natomiast na oddelegowanie do Królestwa ministra M. Suchozaneta $^{41}$. Generał M. Gorczakow, po przebyciu ciężkiej choroby, zmarł w pałacu belwederskim 30 maja 1861 r., a następnie, po przetransportowaniu ciała koleją oraz statkiem, pochowano go w Sewastopolu 19 czerwca 1861 r., zgodnie z wcześniejszym jego życzeniem ${ }^{42}$.

33 [W. Przyborowski], Historia dwóch..., cz. I, t. 2, s. 381 - autor przytacza pogłoskę, że namiestnikowi zaczęły ukazywać się zjawy kobiet ubranych na czarno.

34 Michat Gorczakow do Mikotaja Suchozaneta, [w:] Korespondencja namiestników Królestwa Polskiego z 1861 roku, s. 129; J.K. Ja n ow ski, op. cit., s. 266.

35 Aleksander II do Michata Gorczakowa, Petersburg, 16 (28) V 1861, [w:] Korespondencja namiestników Królestwa Polskiego z 1861 roku, s. 199.

36 M. Berg, Zapiski o powstaniu..., t. 1, s. 248.

37 Mikotaj Kryżanowski do Mikotaja Suchozaneta, Warszawa, 13 (25) V 1861, [w:] Korespondencja namiestników Królestwa Polskiego z 1861 roku, s. 195.

38 M. Berg, Zapiski o powstaniu..., t. 1, s. 296.

39 Mikotaj Suchozanet do Zygmunta Marchelewicza, Petersburg, 14 (26) V 1861, [w:] Korespondencja namiestników Królestwa Polskiego z 1861 roku, s. 195; J.K. Ja n o w s ki, op. cit., s. 267.

40 D. Szpoper, Sukcesorzy Wielkiego Księstwa. Myśl polityczna i dziatalność konserwatystów polskich na ziemiach litewsko-biatoruskich w latach 1904-1939, Gdańsk 1999, s. 5-6.

${ }_{41}$ Piotr Sofianos do Aleksandra Gorczakowa, Warszawa, 14 (26) V 1861, [w:] Korespondencja namiestników Królestwa Polskiego z 1861 roku, s. 196; Aleksander II do Michata Gorczakowa, Petersburg, 15 (27) V 1861, [w:] Korespondencja namiestników Królestwa Polskiego z 1861 roku, s. 197.

42 M. Berg, Zapiski o powstaniu..., t. 1, s. 298, 325; J.K. Ja now ski, op. cit., s. 267; [W. Pr zy b o row ski], Historia dwóch..., cz. I, t. 2, s. 478. 
Z trudną sytuacją w Królestwie musiał teraz zmierzyć się generał adiutant M. Suchozanet, który rozpoczął sprawowanie urzędu od przyjęcia w dniach 2 i 3 czerwca dygnitarzy wojskowych, przedstawicieli duchowieństwa, urzędników i delegacji obywateli miasta ${ }^{43}$. Miał wtedy powiedzieć, żeby „starali się wszelkimi siłami przyczyniać do spokoju, bo gdzie jest spokój, tam idzie interes, gdzie idzie interes, tam jest pieniądz, a gdzie pieniądz, tam swoboda prawdziwa" ${ }^{\prime 4}$. Stolica Królestwa nie była mu obca, ponieważ za rządów księcia I. Paskiewicza służył tam jako dowódca artylerii, a ponadto jego pochodzenie wskazywało na silne związki z polską szlachtą osiadłą na Witebszczyźnie ${ }^{45}$. Urodził się w $1794 \mathrm{r}^{46}$ w niezamożnej rodzinie, która utrzymywała się z uprawiania roli na ziemiach należących do Radziwiłłów. Dzięki matce, która była Polką, nauczył się języka polskiego ${ }^{47}$, natomiast trudności przysparzał mu język rosyjski, głównie w aspekcie zasad pisowni i wymowy ${ }^{48}$. Nigdy też nie otrzymał należytego wykształcenia, a w nadziei na poprawę bytu rodzice posłali go do wojska w $1811 \mathrm{r}^{49}$ Wojna napoleońska pomogła młodemu żołnierzowi w awansie odznaczając się w bitwie pod Połockiem, otrzymał stopień podporucznika, a już w 1828 r. dostał szlify generała majora ${ }^{50}$. Odpowiednią nominację na zastąpienie M. Gorczakowa na stanowisku namiestnika przyjął w Carskim Siole 28 kwietnia 1861 r. - odtąd miał pełnić „zarząd tymczasowy Królestwa Polskiego na prawach namiestnika”"

Suchozanet nie wywierał pozytywnego wrażenia ani w Warszawie, ani w Petersburgu, gdzie uważano go za człowieka o mocno ograniczonych horyzontach, raczej niewychodzących poza ramy wojskowe. Przekonany o czasowości swojego nowego stanowiska, nie interesował się panującymi w Królestwie stosunkami społeczno-politycznymi, a swoją uwagę skupiał jedynie na tym, na czym znał się najlepiej, czyli na armii. Przemierzając ulice Warszawy, chętnie urządzał przeglądy wojsk, kontrolując przede wszystkim ubiór swoich podkomendnych ${ }^{52}$. Jeśli chodzi o kwestię ubioru, to kładł na nią szczególny nacisk, także w stosunku do obywateli miasta, nakazując, aby ci nie nosili żadnych odznak politycznych

43 [W. Przyborowski], Historia dwóch..., cz. I, t. 3: Czerwiec - Grudzień, Kraków 1891, s. 4.

44 Ibidem, s. 6.

45 Ibidem, s. 2.

46 M. Berg, Zapiski o powstaniu..., t. 2, s. 8; Enciktopedija wojennych..., t. 7, Sankt Petersburg 1895, s. 360.

47 M. Berg, Zapiski o powstaniu..., t. 2, s. 3.

48 J.K. Janowski, op. cit., s. 273.

49 Enciktopedija wojennych..., t. 7, s. 360.

50 M. Berg, Zapiski o powstaniu..., t. 2, s. 9, gdzie pokazana jest ścieżka wczesnej kariery wojskowej Suchozaneta: w sierpniu 1812 r. został podporucznikiem, 26 listopada 1812 r. porucznikiem, 12 sierpnia 1814 r. przeniesiono go do artylerii gwardyjskiej, gdzie mianowano go adiutantem dowódcy artylerii I Armii. W 1820 r. został pułkownikiem, w 1828 generałem majorem, a w 1848 generałem porucznikiem. Podczas kampanii węgierskiej przejął dowództwo nad artylerią armii czynnej.

51 [W. Przyborow ski], Historia dwóch..., cz. I, t. 3, s. 2.

52 J.K. Ja nowski, op. cit., s. 276; M. B erg, Zapiski o powstaniu..., t. 2, s. 23. 
ani strojów wyróżniających się pod względem kolorystyki i kroju. Odpowiednie ogłoszenie w tym zakresie rozplakatowano na ulicach miasta 4 czerwca - stało się ono pierwszym wyrazem woli nowego namiestnika względem mieszkańców ${ }^{53}$.

Suchozanet chętnie przebywał w Belwederze, gdzie w zaciszu pałacu poświęcał czas na tworzenie poezji, tym samym nie przywiązując zbytniej wagi do wydarzeń w Królestwie. Sprawowanie urzędu namiestnika początkowo wyraźnie przynosiło mu satysfakcję, ponieważ w liście do cara wręcz błagał o zwłokę w podjęciu decyzji o jego zastępstwie, wskazując, że na zajmowanym urzędzie może być bardziej pożyteczny. Wraz z kolejnymi manifestacjami zmienił swoje stanowisko, prosząc władcę o pośpiech w oddelegowaniu następcy ${ }^{54}$. Wojskowe podejście do sprawy polskiej nie pomagało mu w podejmowaniu decyzji, które wymagały jednak szerszego spojrzenia na problem. Spowodowało to, że wdał się w otwarty konflikt z margrabią Aleksandrem Wielopolskim w obawie przed rozszerzeniem kompetencji administracji cywilnej kosztem wpływów wojskowych. Doprowadziło to do złożenia dymisji przez margrabiego 26 lipca 1861 r. Swoją obecnością w rządzie nie chciał on popierać aktów przemocy i naruszeń tzw. „ustawy o zbiegowiskach”5. Aleksander II, dowiedziawszy się o złożeniu urzędu przez A. Wielopolskiego, w liście do M. Suchozaneta z 1 sierpnia 1861 r. wyraził swoje niezadowolenie z tego faktu ${ }^{56}$, a siedem dni później nakazał, aby margrabia utrzymał stanowisko do przybycia następcy namiestnika, hrabiego Karola Lamberta ${ }^{57}$.

Car musiał zdawać sobie sprawę z faktu, że tymczasowy zarząd nad Królestwem nie rozwiąże problemów kwestii polskiej, dlatego nieustannie poszukiwał godnego następcy M. Suchozaneta. W czerwcu 1861 r. jego pierwszy wybór padł na Pawła Aleksiejewicza Tuczkowa, który piastował urząd generała-gubernatora moskiewskiego, ale ten odmówił carowi przyjęcia zaszczytu, tłumacząc się nieznajomością realiów Królestwa ${ }^{58}$.

53 [W. Pr zyborow ski], Historia dwóch..., cz. I, t. 3, s. 6-7 - są tam wskazane elementy ubioru zabronionego przez Suchozaneta. Na liście znalazły się: czapki rogatywki, czapki kościuszkowskie, kontusze, żupany, kamizelki, halsztuki, krawaty koloru amarantowego, kolorowe buty, a także ubranie charakteryzujące się nietypowym krojem.

54 Mikotaj Suchozanet do Aleksandra II, Warszawa, 7 VI 1861, [w:] M. B erg, Zapiski o powstaniu..., t. 1, s. 326-327; Mikotaj Suchozanet do Aleksandra II, Warszawa, 29 VII (10 VIII) 1861, [w:] Korespondencja namiestników..., t. 1, cz. I, s. 254-255.

55 D. Szpoper, Aleksander Wielopolski..., s. 34; H. Lisicki, op. cit., t. 1, s. 239-242; M. B erg, Zapiski opowstaniu..., t. 2, s. 26 - wskazano tam, że punktem zapalnym w stosunkach Wielopolskiego i Suchozaneta stała się sprawa aresztowania polskich urzędników w Suwałkach. Eskalacja konfliktu wzrosła po wydaniu zgody przez margrabiego na odprawienie nabożeństwa żałobnego za zmarłego księcia Adama Jerzego Czartoryskiego.

56 Aleksander II do Mikotaja Suchozaneta, Krasnoje Sieło, 20 VII (1 VIII) 1861, [w:] Korespondencja namiestników Królestwa Polskiego z 1861 roku, s. 250.

57 AleksanderII do Mikotaja Suchozaneta, Petersburg, 27 VII (8VIII) 1861, [w:] Korespondencja namiestników Królestwa Polskiego z 1861 roku, s. 254.

58 Pawet Tuczkow do Wasyla Gotgorukiego, Moskwa, [brak daty dziennej] VI 1861, [w:] M. Berg, Zapiski o powstaniu..., t. 2, s. 328-329; [W. Przyborowski], Historia dwóch..., cz. I, t. 3, s. 32; 
Aleksander II, postawiony w kłopotliwej sytuacji, zaproponował ten urząd hrabiemu Karolowi Lambertowi. Pod koniec czerwca M. Suchozanet prosił cara o przyspieszenie decyzji o oddelegowaniu swojego następcy, tłumacząc, że „tutaj w ciągu jednego dnia dowie się on więcej o stanie i potrzebach kraju, niż długo ucząc się tego w Petersburgu"59. Zapowiedź jego nominacji na urząd pełniącego obowiązki namiestnika oraz głównodowodzącego I Armią M. Suchozanet otrzymał dopiero 26 lipca 1861 r. $^{60}$, jednak okres oczekiwania na nowego zarządcę przedłużył się do 23 sierpnia, kiedy ten przybył do Warszawy ${ }^{61}$. Lambert przejął obowiązki dwa dni później ${ }^{62}$, a uroczystość z tej okazji odbyła się 27 sierpnia w Zamku Królewskim, gdzie nowy namiestnik przyjął dygnitarzy cywilnych ${ }^{63}$. Suchozanet w raporcie do cara podkreślił, że przekazał hrabiemu Lambertowi „nieustraszoną duchem i dyscypliną armię i kraj”, równocześnie ostrzegając następcę przed „naprawdę niebezpieczną sytuacją wszystkich miejscowości” ${ }^{64}$. Opuścił Warszawę 28 sierpnia ${ }^{65}$, udając się najpierw do Berlina, „dla wzmocnienia psującego się wzroku”, a następnie do Bad Wildbad, gdzie mógł korzystać z leczniczych kąpieli ${ }^{66}$.

Karol Lambert był potomkiem arystokratycznego rodu francuskiego, jednak urodził się w Imperium Rosyjskim, gdzie otrzymał następnie należyte wykształcenie i wychowanie. Już od lat szkolnych wyróżniał się na tle swoich kolegów ponadprzeciętną inteligencją i urodą, co pomagało mu w zyskiwaniu sobie sympatii otoczenia. Wzorem ojca, swoją karierę zawodową związał z armią, rozpoczynając służbę w gwardii konnej. Brał udział w kampanii wojennej na Kaukazie, jednak nie miał okazji wykazania się w walce i w kwietniu $1841 \mathrm{r}$. powrócił do Sankt Petersburga, gdzie los się do niego uśmiechnął, gdy - zauważony przez cesarza podczas jednej z defilad - został adiutantem skrzydłowym, a w 1850 r. awansował, obejmując dowództwo pułku. Polskę miał okazję poznać, stacjonując ze swoją jednostką

por. z: J.K. Ja n ow ski, op. cit., s. 282 - jak pisze tam autor, kandydatura Karola Lamberta na stanowisko namiestnika Królestwa Polskiego pojawiła się już w chwili nominacji Suchozaneta, a prawie trzymiesięczny okres oczekiwania wynikał z konieczności „dokończenia swojej edukacji” i uzyskania stopnia generała kawalerii.

59 Mikotaj Suchozanet do Aleksandra II, Warszawa, 18 (30) VI 1861, [w:] Korespondencja namiestników Królestwa Polskiego z 1861 roku, s. 217.

60 Aleksander II do Mikotaja Suchozaneta, Petersburg, 14 (26) VII 1861, [w:] Korespondencja namiestników Królestwa Polskiego z 1861 roku, s. 244-245.

${ }_{61}$ M. B erg, Zapiski o powstaniu..., t. 2, s. 44.

62 Karol Lambert do Aleksandra II, Warszawa, 13 (25) VIII 1861, [w:] Korespondencja namiestników Królestwa Polskiego z 1861 roku, s. 262.

63 [W. Przyborow ski], Historia dwóch..., cz. I, t. 3, s. 206-207.

${ }^{64}$ Mikotaj Suchozanet do Aleksandra II, Warszawa, 14 (26) VIII 1861, [w:] Korespondencja namiestników Królestwa Polskiego z 1861 roku, s. 263.

65 F. Ra motowska, Zarzad Wojennego..., s. 175.

66 Mikotaj Suchozanet do Aleksandra II, Warszawa, 18 (30) VII 1861, [w:] Korespondencja namiestników Królestwa Polskiego z 1861 roku, s. 246; F. R a m o tow sk a, Zarząd Wojennego..., s. 159. 
w Międzyrzecu na Podlasiu, gdzie okrył się złą sławą wśród podkomendnych, oskarżających go o defraudację pieniędzy. Wieść o tym dotarła do cesarza, jednak ze względu na powszechność takich praktyk w carskiej armii nie wzbudziło to większego zainteresowania w środowisku wojskowym. Kolejny jego awans, na stopień generała porucznika, dokonał się w Moskwie, gdzie przebywał z okazji koronacji cara Aleksandra II w 1856 r., a dwa lata później objął zarząd komisji do spraw likwidacji kolonii wojskowych na południu Imperium Rosyjskiego. Następnie powrócił do Sankt Petersburga, gdzie został mianowany na pomocnika inspektora strzelców celnych ${ }^{67}$. Złamanie ręki w 1860 r. pokrzyżowało mu plany i zmusiło do wyjazdu na rekonwalescencję do Paryża, gdzie otrzymał niepokojące wieści o wydarzeniach w Królestwie wraz z informacją o planowanej dla niego nominacji na fotel generała-gubernatora warszawskiego ${ }^{68}$. Wracając z rekonwalescencji w Paryżu do Moskwy, na początku czerwca zatrzymał się na pięć dni w Warszawie w celu zapoznania się $\mathrm{z}$ sytuacją $\mathrm{w}$ Królestwie, aby następnie swoje spostrzeżenia zreferować carowi ${ }^{69}$. Jego pobyt w cesarstwie to okres szybkich awansów do stopnia generała kawalerii oraz nominacji na urząd pełniącego obowiązki namiestnika i głównodowodzącego I Armią, co dokonało się 18 sierpnia $1861 \mathrm{r}^{70}$

W nowym namiestniku pokładano nadzieję na unormowanie sytuacji w Królestwie poprzez sprawne przeprowadzenie reform oraz neutralizację ruchu rewolucyjnego. Car dążył do dalszego rozszerzenia autonomii, pod warunkiem że jego poddani udowodnią chęć współpracy przez poszanowanie prawa ${ }^{71}$. Aleksander II potrzebował zatem w zarządzie Królestwa osoby inteligentnej, wykształconej oraz energicznej, aby mogła sprostać temu trudnemu wyzwaniu. Hrabia Lambert spełniał wszystkie te warunki, chociaż obawiano się jego liberalnego podejścia do sprawy polskiej, dlatego wraz z K. Lambertem pojawił się w Warszawie nowy generał-gubernator Aleksander Gerstenzweig, który miał pełnić funkcję kontrolną w razie nadmiernej pobłażliwości namiestnika. Łagodne usposobienie Lamberta próbował wykorzystać margrabia A. Wielopolski, który zaraz po przybyciu tego pierwszego do Królestwa nakreślił mu swój plan załagodzenia sytuacji poprzez wprowadzenie szeregu reform, takich jak na przykład przywrócenie języka polskiego w administracji, zaakceptowanie barw narodowych, rozdzielenie administracji wojskowej i cywilnej, włączenie urzędu generała-gubernatora do struktury Wydziału Spraw Wewnętrznych i Policji i wiele innych ${ }^{72}$. Lambert zbył A. Wielopolskiego stwierdzeniem, że nie podejmie

${ }_{67}$ M. Berg, Zapiski o powstaniu..., t. 2, s. 13-15.

68 Ibidem, s. 15.

${ }^{69}$ Ibidem, s. 16, 30 - autor przytacza słowa K. Lamberta odnoszące się do jego nominacji: „Zmiłujcie się, dajcie spokój z powinszowaniami. W Petersburgu tylko rękę złamałem, a w Warszawie mogę kark skręcić”.

$70 \quad$ Ibidem, s. 27.

${ }^{71}$ Korespondencja namiestników Królestwa Polskiego z 1861 roku, s. 267.

72 D. Szpoper, Aleksander Wielopolski..., s. 37-38 - tam szerzej o żądaniach politycznych Aleksandra Wielopolskiego względem K. Lamberta. 
tak istotnych decyzji przed dokładnym zapoznaniem się z problemem. Poczynił jednak pierwszy krok, usuwając z ulic Warszawy oddziały wojska ${ }^{73}$. Namiestnik jednak coraz częściej spotykał się z negatywnymi opiniami na temat A. Wielopolskiego i jego reform, szczególnie ze strony rewolucyjnie nastawionego mieszczaństwa, które widziało w nim największą przeszkodę w urzeczywistnieniu swoich celów politycznych ${ }^{74}$. Własne stanowisko w sprawie margrabiego zajął także cesarz w liście do K. Lamberta z 1 września 1861 r., w którym wyraził swoje zadowolenie z pozostawienia margrabiego na stanowisku, dodając jednak, aby namiestnik nie poddał się jego wpływowi i dał mu wyraźnie do zrozumienia, że w razie niewykonywania rozkazów zostanie zwolniony z urzędu. Rozczarowany doniesieniami z Litwy o sierpniowych wydarzeniach w Wilnie i Kownie oraz nastrojach rewolucyjnych w Królestwie wspomniał, że „bez stanu wojennego tam i w Cesarstwie [Królestwie] nie osiągną tego, co on chce, czyli zaistnienia należytego porządku"75. Manifestacje i patriotyczne nabożeństwa nie ustawały, dlatego wprowadzenie stanu wojennego było tylko kwestią wybrania odpowiedniego momentu. Car naciskał na K. Lamberta, aby ten podjął bardziej zdecydowane kroki, na wzór rozwiązań na Litwie ${ }^{76}$, gdzie 5 września w kilku powiatach guberni wileńskiej, kowieńskiej, grodzieńskiej oraz w miastach gubernialnych wprowadzono stan wojenny ${ }^{77}$. Na kolejne informacje o zaburzeniach w Królestwie car reagował nakazem zastosowania rozwiązania ostatecznego, zmuszając Lamberta do balansowania pomiędzy jego oczekiwaniami a sprawnym przeprowadzeniem wyborów do rad powiatowych. Reforma samorządowa doskonale ukazała różnice w polskiej idei odzyskania niepodległości i później podkreśliła podział na dwa ugrupowania polityczne - białych oraz czerwonych. Ci ostatni widzieli w wyborach do rad podstęp carskich władz, a umiarkowani szansę na rozwój kraju i kolejny krok do dalszych reform ${ }^{78}$.

Namiestnik zdecydował się na wprowadzenie stanu wojennego 2 (14) października 1861 r., czyli w przeddzień rocznicy śmierci Tadeusza Kościuszki. W trakcie trwania nabożeństw, gdy zebrani w kościołach śpiewali pieśni patriotyczne, K. Lambert wydał rozkaz otoczenia trzech warszawskich świątyń i aresztowania dorosłych mężczyzn po ich

73 [W. Przyborowski], Historia dwóch..., cz. I, t. 3, s. 214-217.

74 Ibidem, s. 222-223.

75 Aleksander II do Karola Lamberta, Odessa, 20 VIII (1 IX) 1861, [w:] Korespondencja namiestników Królestwa Polskiego z 1861 roku, s. 270-271.

76 Aleksander II do Karola Lamberta, Liwadia, 3 (15) IX 1861, [w:] Korespondencja namiestników Królestwa Polskiego z 1861 roku, s. 281; P. Dąbrowski, „Litewski Wielopolski” - czyli program hrabiego Wiktora Starzeńskiego przed 1863 r., [w:] Próba ustrojowej rekonstrukcji..., s. 76; [W. Pr zyb o row ski], Historia dwóch..., cz. I, t. 3, s. 228.

77 Korespondencja namiestników Królestwa Polskiego z 1861 roku, s. 281 (przypis od autora); D. Sz po per, Pomiędzy caratem a snem o Rzeczypospolitej. Myśl polityczna i dziatalność konserwatystów polskich w guberniach zachodnich Cesarstwa Rosyjskiego w latach 1855-1862, Gdańsk 2003, s. 94-111 - tam szerzej o eskalacji konfliktu rosyjsko-polskiego.

78 F. Ra mo tow sk a, Narodziny tajemnego państwa polskiego 1859-1862, Warszawa 1990, s. 102-103. 
wyjściu na ulice. Akcję przeprowadzono pomyślnie tylko w jednym przypadku, a w pozostałych wojsko zmuszone było do wtargnięcia do kościołów, gdy ludność odmówiła ich opuszczenia $^{79}$. O przeprowadzonym aresztowaniu generał-gubernator A. Gerstenzweig zameldował namiestnikowi, podając liczbę około 1,6 tys. ${ }^{80}$ osadzonych w Cytadeli. Lambert przestraszył się tak dużej liczby aresztantów, bo wiedział, że warszawiacy mogą zareagować gwałtownie na te informacje, doprowadzając do wybuchu powstania. W mieście faktycznie zawrzało, jednak namiestnik starał się tłumić wszelkie przejawy postaw antyrządowych przy pomocy oddziałów kozackich, które siłą likwidowały zbiegowiska ${ }^{81}$. Nie mógł jednak przewidzieć stanowiska duchowieństwa, które - w obliczu „znieważenia kościołów" przez carskich żołnierzy 16 października 1861 r. - wydało odezwę o zamknięciu wszystkich świątyń w mieście ${ }^{82}$. W obawie przed negatywnymi konsekwencjami K. Lambert polecił uwolnienie prawie wszystkich więźniów. Odbyło się to w tajemnicy przed generałem-gubernatorem, który dowiedziawszy się przez przypadek o tym zarządzeniu, pojechał do zamku, gdzie spotkał się z K. Lambertem. Konfrontacja miała niezwykle gwałtowny przebieg, podczas niej obaj nie szczędzili sobie wyzwisk, a A. Gerstenzweig miał oskarżyć namiestnika o pobłażliwość, niezdecydowanie, a nawet o zdradę ${ }^{83}$. W celu uniknięcia skandalu zdecydowali się na zakończenie sporu honorowo, w tak zwanym pojedynku amerykańskim, czyli poprzez popełnienie samobójstwa. Nieszczęśliwy los padł na generała-gubernatora ${ }^{84}$.

O próbie samobójczej A. Gerstenzweiga namiestnik poinformował cara jeszcze tego samego dnia. Doniósł jednocześnie o bardzo ciężkim stanie swojego zdrowia i postępującej chorobie, dodając na koniec: „Na litość boską, przyślij kogoś na nasze miejsca” ${ }^{35}$. Swoją prośbę powtórzył w liście z 18 października, w którym pisal, że jego „nieuleczalna choroba zmniejsza w nim wszystkie cechy, niezbędne dla zarządzania krajem w tych krytycznych okolicznościach" ${ }^{\prime 86}$. Cesarz w końcu przyjął błagania namiestnika, wyznaczając następcę w osobie generała adiutanta Aleksandra Lüdersa, jednak do czasu jego przybycia zarząd

79 [W. Przyborowski], Historia dwóch..., cz. I, t. 3, s. 360-373.

80 Ibidem, s. 374 (przypis od autora) - są tam podane źródła wskazujące różne dane liczbowe dotyczące aresztowanych mężczyzn. Oscylują one jednak w granicach 1600-1700 osób.

$81 \quad$ Ibidem, s. 375.

82 M. Berg, Zapiski o powstaniu..., t. 2, s. 90-91.

83 Ibidem, s. 93.

84 Ibidem, s. 95; [W. Pr zyb o row ski], Historia dwóch..., cz. I, t. 3, s. 385. Podobne opisy wydarzeń wskazują na niedostateczną siłę wystrzału, co może również potwierdzić teorię Michaiła Berga, że zamachu na własne życie generał-gubernator dokonał przy użyciu rewolweru starego typu, z systemem sześciu luf, z którego samobójstwo popełnił także jego ojciec w 1849 r. M. B erg, Zapiski o powstaniu..., t. 2, s. 96.

85 Karol Lambert od Aleksandra II, Warszawa, 5 (17) X 1861, [w:] Korespondencja namiestników Królestwa Polskiego z 1861 roku, s. 313.

86 Karol Lambert od Aleksandra II, Warszawa, 6 (18) X 1861, [w:] Korespondencja namiestników Królestwa Polskiego z 1861 roku, s. 317-318. 
nad Królestwem miał objąć ponownie generał M. Suchozanet. Te nagłe zmiany personalne wstrząsnęły A. Wielopolskim, który dowiedziawszy się o przyjeździe znienawidzonego generała, po raz drugi posłużył się groźbą dymisji. Namiestnik bezskutecznie próbował nakłonić margrabiego do wycofania swojej decyzji, jednak w danym momencie prawdopodobnie bardziej przejęty był swoim wyjazdem na Maderę niż sprawą polską ${ }^{87}$. Nie zwracając na siebie uwagi, opuścił Warszawę 23 października, dzień po spotkaniu z A. Wielopolskim. Dzień wcześniej natomiast przyjechał M. Suchozanet, który objął urząd z nakazem prowadzenia zdecydowanej polityki wobec miejscowej ludności. Spełniło się jego marzenie, gdy z poparciem samego cara oraz w warunkach stanu wojennego mógł zacząć realizowanie swoich planów z charakterystyczną dla siebie żołnierską surowością. Rządy rozpoczął jednak od tradycyjnych już przeglądów wojsk, jak również od podsycania konfliktu z A. Wielopolskim, którego traktował jak przeszkodę w urzeczywistnieniu swoich zamiarów. Informując Aleksandra II o niesubordynacji i szkodliwości margrabiego, sugerował jego wyjazd z Warszawy, do czego car przychylił się, wydając 30 października rozkaz, aby A. Wielopolski udał się do Petersburga pod groźbą osadzenia w Cytadeli ${ }^{88}$. W ten sposób rosyjskie środowisko wojskowe w Warszawie, a przede wszystkim M. Suchozanet, pozbyło się swojego największego politycznego wroga, chociaż później miało się okazać, że wydarzenia potoczyły się z korzyścią dla margrabiego ${ }^{89}$. Odtąd namiestnik bez żadnych ograniczeń mógł skrupulatnie wypełniać carskie zalecenia, likwidując wszelkie przejawy buntu oraz przeprowadzając masowe aresztowania polskich agitatorów. Ze względu na przepełnienie cel w Cytadeli i policyjnych aresztów decydowano się na usuwanie opozycjonistów z Królestwa, wysyłając ich w głąb carskiej Rosji albo wcielając do wojska. Takie rozwiązania cieszyły cara, który, otrzymując dodatkowo telegramy z informacją o spokoju panującym w Warszawie, w końcu zyskał potwierdzenie skuteczności prowadzonej polityki represji. M. Suchozanet nie zagościł na długo w Warszawie, bo już 14 listopada 1861 r. wyjechał do Petersburga, gdzie zdymisjonowano go ze stanowiska ministra wojny, przekazując jednak nominację na członka Rady Państwa. Imperator potrzebował odtąd kogoś, kto mógłby poprowadzić dzieło Lamberta, sprawując w Królestwie rządy twardej ręki w celu uspokojenia miejscowej ludności ${ }^{90}$.

Era rządów kolejnego, czwartego już namiestnika w ciągu roku, rozpoczęła się od nominacji na to stanowisko, wydanej 21 października 1861 r. w Liwadii. Generał adiutant

87 M. B erg, Zapiski o powstaniu..., t. 2, s. 99 - autor precyzuje, że K. Lambert początkowo udał się do Paryża, gdzie poznał swoją przyszłą żonę, a dopiero później wyjechał na Maderę. Zaślubiny odbyły się na początku 1865 r., jednak zmarł on jeszcze w tym samym roku.

88 F. Ra motow ska, Zarzad Wojennego..., s. 257; Mikotaj Suchozanet do Aleksandra II, Warszawa, 13 (25) X 1861, [w:] Korespondencja namiestników Królestwa Polskiego z lat 1861-1863, red. S. Kieniewicz, I. Miller, Wrocław-Warszawa-Kraków-Gdańsk 1973, s. 6.

89 J.K. Jan owski, op. cit., s. 307.

90 F. Ramotowska, Zarząd Wojennego..., s. 253, 259, 261. 
w stanie spoczynku Aleksandr Mikołajewicz Lüders, mający już 70 lat, objął ten urząd na czas określony, do momentu powrotu hrabiego K. Lamberta. Pochodził z Niemiec i podobnie jak jego poprzednicy swoje życie związał z armią, w której miał okazję wykazania się, biorąc udział w wojnach napoleońskiej, tureckiej, w kampanii polskiej z 1831 r. i wojnie kaukaskiej. Oficjalnie ze względu na zły stan zdrowia poprosił w 1856 r. o zwolnienie ze służby czynnej, po czym zamieszkał nad Morzem Czarnym. Wybór cara, który padł właśnie na A. Lüdersa, był podyktowany jego szerokim doświadczeniem w prowadzeniu pacyfikacji. Nieprzeciętny życiorys nowego namiestnika był urozmaicony nie tylko skandalami na tle finansowym, ale także romansami z żonami oficerów ${ }^{91}$. Prawdopodobnie popadnięcie w niełaskę, a nie zły stan zdrowia zmusiło generała do opuszczenia szeregów armii ${ }^{92}$. Awanturnicki charakter A. Lüdersa musiał osłabnąć $z$ wiekiem, ponieważ kandydat na namiestnika nie ucieszył się z tego zaszczytu, a swoją niechęć ttumaczył nieznajomością języka, mieszkańców Warszawy oraz brakiem odpowiedniego przygotowania w zakresie prowadzenia administracji cywilnej. Car nie przyjął tych wymówek, więc zasłużony generał musiał przystać na polecenie imperatora. Poprosił jednak o przydzielenie mu do pomocy na stanowisku wojennego generała-gubernatora generała Artura Niepokojczyckiego, który był jego dawnym szefem sztabu. Ten jednak odmówił przyjęcia nominacji, podobnie jak generał Aleksander Timaszew $^{93}$. Z pewnością tajemnicza śmierć generała Gerstenzweiga nie wpływała zachęcająco na decyzję jego następców. W związku z tym car zaproponował na to miejsce generała lejtnanta Mikołaja Kryżanowskiego, mianując go 20 listopada 1861 r. Skupił on w swoich rękach nie tylko władzę policyjną, ale także wojskową - jako szef sztabu I Armii94.

Aleksandr Lüders przyjechał do Warszawy 5 listopada 1861 r., a trzy dni później objął swój urząd, o czym poinformował cara w telegramie z 9 listopada ${ }^{95}$. Namiestnik obiecał kontynuowanie odpowiedniej polityki w warunkach stanu wojennego ${ }^{96}$, jednak pod pozornym spokojem w mieście, o którym informował cara ${ }^{97}$, krył się rosnący w siłę podziemny ruch narodowościowy. Ze względu na liczne patrole wojskowe, wzmocnione oddziałami kozaków, oraz w dalszym ciągu zamknięte kościoły Polacy nie mieli możliwości demonstrowania swoich antyrządowych postaw ${ }^{98}$. Ograniczyły się one jedynie do noszenia

91 M. Berg, Zapiski o powstaniu..., t. 2, s. 104-105.

92 Ibidem, s. 106-107.

93 Aleksander II do Aleksandra Lüdersa, Carskoje Sieło, 31 X (12 XI) 1861, [w:] Korespondencja namiestników..., t. 1, cz. II, s. 37.

$94 \quad$ F. Ramotowska, Zarzad Wojennego..., s. 276-277.

95 Aleksander Lüders do Aleksandra II, Warszawa, 28 X (9 XI) 1861, [w:] Korespondencja namiestników Królestwa Polskiego z lat 1861-1863, s. 31.

96 Ibidem.

${ }_{97}$ Aleksander Lüders do Aleksandra II, Warszawa, 31 X (12 XI) 1861, [w:] Korespondencja namiestników Królestwa Polskiego z lat 1861-1863, s. 37.

98 F. Ramotowska, Zarzad Wojennego..., s. 277-278. 
charakterystycznych żałobnych strojów, emblematów i odznak patriotycznych, czemu namiestnik wkrótce wypowiedział wojnę. Spacerując samotnie ulicami Warszawy, miał odwiedzać sklepiki z drobiazgami, co w kolejnych dniach przyniosło zaostrzenie przepisów policyjnych dotyczących sprzedaży symboli narodowych. Policja sukcesywnie wyłapywała chłopców trudniących się rozprowadzaniem tych przedmiotów na ulicach Warszawy, co doprowadziło do przeniesienia działalności do podziemia. Jak się miało później okazać, była to jedynie namiastka kolejnych posunięć A. Lüdersa. Podobnie do swojego poprzednika, w pierwszych dniach swoich rządów organizował przeglądy wojsk, w imieniu cara dziękując żołnierzom za „ciężką i gorliwą służbę" się nowemu namiestnikowi, bezskutecznie próbowali odgadną́ jego cechy charakteru i zamiary. $Z$ pewnością nie przypuszczali, że wiekowy już generał zaostrzy represje, prowadząc „politykę strachu” ${ }^{100}$. Swoje polityczne cele zawarł w trzech punktach, a były to: usunięcie z kraju osób niepożądanych, pozbawienie mieszkańców pretekstu do wystąpień po zniesieniu stanu wojennego oraz uspokojenie duchowieństwa. Uważał, że drogą do ich osiągnięcia jest ścisłe przestrzeganie przepisów o stanie wojennym, przeprowadzenie poboru rekrutów w miastach najsilniej dotkniętych nastrojami rewolucyjnymi, sprawne wprowadzenie reform samorządowych, jak również obsadzenie na czele archidiecezji warszawskiej osoby zaufanej, o nastawieniu prorządowym. Otwarcie świątyń było dla niego sprawą najpilniejszą, czego dowodem była radykalna próba szantażu na duchownych, polegająca na wstrzymaniu im wypłat poborów etatowych ${ }^{101}$. Należy przy tym wspomnieć, że w nocy z 12 na 13 listopada aresztowano ks. Antoniego Białobrzeskiego, administratora archidiecezji warszawskiej, który odmówił otwarcia świątyń w mieście. W trakcie przesłuchań miał podobno przerzucić winę na społeczeństwo, jednak sąd wojenny mimo to odebrał mu godność kapłańską i order św. Anny, a następnie, 7 grudnia 1861 r., skazał na karę śmierci przez rozstrzelanie. $\mathrm{Na}$ tę nowinę w Warszawie znowu zawrzało. Namiestnik mógł wykonać wyrok natychmiast, jednak w obawie przed negatywnymi skutkami odwołał się do cara, który nakazał wstrzymanie egzekucji ${ }^{102}$. Karę śmierci zamieniono na pozbawienie wolności w twierdzy w Bobrujsku z pozostawieniem godności kapłańskiej oraz orderu ${ }^{103}$. Po tych wydarzeniach poszukiwano zastępcy na stanowisko administratora, prosząc w tej sprawie o opinię margrabiego A. Wielopolskiego. Po konsultacji z Konstantym Łubieńskim wskazał on na osobę ks. Zygmunta Felińskiego. Kandydaturę tę zaakceptował car, zlecając rozpoczęcie negocjacji ze Stolicą Apostolską, po czym Ojciec Święty dokonał oficjalnego wyboru Z. Felińskiego

\footnotetext{
99 M. Berg, Zapiski o powstaniu..., t. 2, s. 112.

100 Aleksander Lüders do Aleksandra II, Warszawa, 3 (15) XI 1861, [w:] Korespondencja namiestników Królestwa Polskiego z lat 1861-1863, s. 38-41.

101 F. R a motowska, Zarzad Wojennego..., s. 297-298.

102 J.K. Jan owski, op. cit., s. 308.

103 M. B erg, Zapiski o powstaniu..., t. 2, s. 116.
} 
i 6 stycznia 1862 r. prekonizował go na arcybiskupa warszawskiego ${ }^{104}$. Tym samym spełniły się oczekiwania namiestnika w kontekście otwarcia kościelnych bram, co nastąpiło w dniach 13 i 14 lutego 1862 r. Arcybiskup Z. Feliński w katedrze pod wezwaniem św. Jana odprawił nabożeństwo i zwrócił się do wiernych, aby wytrwali w wierze, jednak nie sprzeciwiając się przy tym władzy. Wywołało to negatywne emocje wśród zebranych, którzy na te słowa opuścili świątynię ${ }^{105}$.

Namiestnik konsekwentnie realizował zamierzone cele z pomocą naczelników wojennych, dla których 15 stycznia 1862 r. wydał specjalną instrukcję. Precyzowała ona warunki użycia wojsk oraz sposoby nadzorowania władz cywilnych, a przede wszystkim policji. Naczelnicy otrzymali uprawnienia do swobodnego przemieszczania wojsk w przypadku zaistnienia takiej potrzeby oraz wydania rozkazu użycia broni palnej przeciw demonstrantom, jednak tylko w ściśle określonych wypadkach. Wojsko mogło zostać wykorzystane jedynie w razie konieczności, a obowiązek dokonywania aresztowań i dbania o porządek powierzono policji. Namiestnik w instrukcji zawarł także nakaz właściwego zachowywania się żołnierzy względem ludności cywilnej oraz szybkiego rozpatrywania ewentualnych sporów na tej linii. Poza tym naczelnicy nie mogli włączać się w spory chłopów i ziemian, a sprawy te mieli kierować do właściwych organów cywilnych. Na tym przykładzie widać wyraźną zmianę prowadzenia polityki wewnętrznej przez A. Lüdersa, który do walki z ruchem narodowościowym próbował włączyć organy administracyjne, aby represje nie wychodziły z inicjatywy Rosjan, a samych Polaków. Praktyka okazała się zupełnie inna od postanowień instrukcji. Naczelnicy, otrzymując większą swobodę w działaniu, nie złagodzili sposobu postępowania wobec podległej ludności, a wręcz nasilili represje ${ }^{106}$.

O ile na prowincji udało się wprowadzić względny spokój, o tyle większy problem stanowił ruch narodowy zakorzeniony w stolicy Królestwa. Lüders meldował carowi, że pomimo surowych przepisów, nie udało się zlokalizować głównych działaczy polskiego podziemia. W Warszawie w dalszym ciągu trwały aresztowania, przede wszystkim osób, które demonstrowały na ulicach swoje polityczne przekonania, pokazując się w niewłaściwych strojach lub z przypiętymi patriotycznymi emblematami. Zaczęto także wprowadzać represje względem aktywistów polskich jeszcze sprzed wprowadzenia stanu wojennego. Rewizji poddano wyroki w najgłośniejszych sprawach, jak na przykład związanych z manifestacjami lutowymi czy incydentami z udziałem młodzieży akademickiej. Środki te jednak nie przyniosły oczekiwanego efektu w postaci aresztowania głównych organizatorów manifestacji lub wydawców podziemnej prasy ${ }^{107}$. Oprócz stosowania represji A. Lüders prowadził

\footnotetext{
104 Ibidem, s. 124-125.

105 Ibidem, s. 137-141, gdzie zostało przytoczone przemówienie arcybiskupa Z. Felińskiego.

106 F. Ra motowska, Zarzad Wojennego..., s. 286-290.

107 Ibidem, s. 304, 312, 338.
} 
także grę polityczną w celu zjednania sobie tej części społeczeństwa, która była przychylnie nastawiona do jego rządów, dlatego jeszcze na początku 1862 r. pojawiły się pierwsze oznaki łagodzenia dotychczasowego kursu, których wyrazem było otwarcie w Warszawie Teatru Wielkiego, Teatru Rozmaitości, parków miejskich oraz szkóó ${ }^{108}$. Bynajmniej nie była to inicjatywa namiestnika, a z pewnością cara i jego doradców, którzy za namową A. Wielopolskiego nieco zmienili politykę względem Królestwa, podkreślając jednak, że Polakom należy się wyłącznie autonomia administracyjna. O konstytucji, własnej armii czy autonomii politycznej nie mogło być mowy ${ }^{109}$.

W marcu 1862 r. namiestnik w liście do cara zdobył się na samokrytykę, pisząc, że stosowana przemoc względem ludności nie przyniosła pożądanych zmian, a wręcz zwiększyła niechęć do władzy. Zaproponował tym samym projekt konkretnych rozwiązań, opartych na wprowadzeniu kompleksowych reform administracyjnych. Nie chciał przy tym rezygnować z dotychczasowego systemu represji względem polskich „demagogów”"110. Car zaakceptował pomysły A. Lüdersa i zgodził się na powołanie specjalnych komitetów do opracowania odpowiednich projektów reform ${ }^{111}$. Namiestnik posunął się dalej i zaproponował wciągnięcie do prac nie tylko urzędników komisji rządowych, ale także osób postronnych. Ten zabieg propagandowy, choć o wiele spóźniony, miał na celu pokazanie, że ruch narodowy w Królestwie Polskim osłabł, a jego działacze zajęli się naprawianiem administracji. Na początku roku mogłoby się wydawać, że polityka A. Lüdersa przynosiła zamierzone efekty, jednak wraz z nadejściem wiosny odżyły nastroje patriotyczne. Namiestnik obawiał się manifestacji z okazji rocznicy krwawych wydarzeń kwietniowych z zeszłego roku. Polacy zwrócili się nawet z prośbą do arcybiskupa o celebrowanie jednego z nabożeństw za poległych, jednak ten odmówił, czym naraził się niektórym kręgom osób. W kościołach odbyły się stosowne uroczystości, ale do manifestacji nie doszło ${ }^{112}$. Po Warszawie zaczęła krążyć pogłoska, że powstanie może wybuchnąć w okresie świąt Wielkiej Nocy, w związku z czym namiestnik odwołał swój wyjazd do Petersburga. Plotki nie sprawdziły się, a święta przebiegły spokojnie, dlatego 25 kwietnia 1862 r. A. Lüders opuścił Warszawę. W jego zastępstwie pozostał w mieście generał Kryżanowski, który wykorzystując nieobecność namiestnika, niezwykle brutalnie rozprawiał się z wszelkimi przejawami postaw patriotycznych

108 J.K. Janowski, op. cit., s. 320.

109 F. Ramotowska, Zarzad Wojennego..., s. 353.

110 Aleksander Lüders do Aleksandra II, Warszawa [Petersburg], 16 (28) IV 1862, [w:] Korespondencja namiestników Królestwa Polskiego z lat 1861-1863, s. 121.

111 F. Ramotowska, Zarząd Wojennego..., s. 379-380; Aleksander II do Aleksandra Lüdersa, Petersburg, 15 (27) III 1862, [w:] Korespondencja namiestników Królestwa Polskiego z lat 1861-1863, s. 111.

112 F. Ramotowska, Zarząd Wojennego..., s. 386-387 - autorka wspomina także o czynie kapitana warszawskiej stacji telegraficznej Aleksandrowa, który poznał treść telegramu cara do namiestnika, mówiącego o zastosowaniu broni białej i kartaczy w stosunku do ewentualnych demonstrantów. Telegrafista zmienił treść tej wiadomości, informując A. Lüdersa, aby ten działał łagodnie. 
manifestowanych dnia 3 maja $^{113}$. Niezadowalające efekty represji oraz konflikt z arcybiskupem w związku z aresztowaniami księży doprowadziły do tego, że A. Lüders przedłożył carowi wniosek o rozwiązanie Zarządu Wojennego Generał-Gubernatora Warszawskiego. Tym samym winą za zły stan polityki wewnętrznej obarczył Kryżanowskiego, którego gwałtowne postępowanie nie pasowało do nowej wizji namiestnika. Car zgodził się z kierunkiem zmian w Królestwie, jednak w liście z 28 maja 1862 r. przedstawił własne rozwiązania. Nowym namiestnikiem miał zostać brat cara, wielki książę Konstanty Mikołajewicz Romanow, a na naczelnika zarządu cywilnego miano powołać margrabiego A. Wielopolskiego. Pomimo tych niepomyślnych dla A. Lüdersa informacji zgodził się on na pozostanie w Warszawie w celu rozwiązania urzędu wojennego generała-gubernatora oraz udzielenia wskazówek swojemu następcy, który zwrócił się do niego o pomoc w przejmowaniu obowiązków ${ }^{114}$.

Nominację na stanowisko namiestnika wielki książę Konstanty przyjął 8 czerwca, jednak przybył do Warszawy dopiero 3 lipca ${ }^{15}$. Do tego czasu władzę sprawował A. Lüders, dla którego pobyt w Królestwie nie zakończył się pomyślnie. Dnia 27 czerwca w Ogrodzie Saskim przeprowadzono zamach na jego osobę, w efekcie którego został ranny. Mówiło się, że dokonał tego carski oficer w zemście za stracenie dzień wcześniej trzech żołnierzy oskarżonych o działalność rewolucyjną ${ }^{116}$. Za trudy służby i zasługi względem Rosji oraz Królestwa Polskiego A. Lüders otrzymał tytuł hrabiowski oraz dożywotnią pensję w wysokości 25 tys. rubli rocznie, dwunastoletnią dzierżawę wartą 14 tys. rubli rocznie, jak również 10 tys. rubli na wyjazd w celu rekonwalescencji.

W nowym namiestniku oraz nowym naczelniku zarządu cywilnego car pokładał nadzieję, że zapoczątkują oni okres symbolizujący pojednanie, co miały przypieczętować kolejne ustępstwa i reformy. $Z$ drugiej jednak strony nigdy już nie miano zrezygnować z polityki strachu ${ }^{117}$, doprowadzając tym samym do wybuchu powstania w $1863 \mathrm{r}$. Bez wątpienia decydujący w tym względzie był rok 1861, kiedy niezdecydowanie cara oraz niekompetencja namiestników doprowadziły społeczeństwo polskie do utraty zaufania względem rosyjskich zarządców. Namiestnicy ujawnili swoją nieznajomość realiów Królestwa, złe przygotowanie do sprawowania władzy cywilnej oraz sztywne trzymanie się reguł wojskowych. Dawało to możliwość swobodnego rozwoju ruchu narodowego, dla którego rosyjski terror był jedynie kolejnym argumentem do budowania silnej pozycji. W końcu urósł w taką siłę, której nie można było zahamować jedynie przy pomocy aparatu represji.

113 J.K. Janowski, op. cit., s. 331.

114 Konstanty do Aleksandra Lüdersa, Petersburg, 18 (30) V 1862, [w:] Korespondencja namiestników Królestwa Polskiego z lat 1861-1863, s. 143-144.

115 F. R a mo tow sk a, Zarząd Wojennego..., s. 413; por. z: J.K. Ja n ow ski, op. cit., s. 339 - autor wskazuje, że wielki książę Konstanty przyjechał do Warszawy 2 lipca wieczorem.

116 F. Ramotowska, Zarzad Wojennego..., s. 413.

117 Ibidem, s. 415. 


\section{BIBLIOGRAFIA}

Źródła:

„Gazeta Narodowa”, rocznik 1881.

„Gazeta Lwowska”, rocznik 1887.

Korespondencja namiestników Królestwa Polskiego z 1861 roku, red. S. Kieniewicz, I. Miller, Wroclaw-Warszawa-Kraków 1964.

Korespondencja namiestników Królestwa Polskiego z lat 1861-1863, red. S. Kieniewicz, I. Miller, Wrocław-Warszawa-Kraków-Gdańsk 1973.

\section{Opracowania:}

Berg M., Zapiski o powstaniu polskim 1863 i 1864 i poprzedzajacej powstanie epoce demonstracji od 1856 r., t. 1-2, Kraków 1898.

Enciktopedija wojennych i morskich nauk, t. 2, red. gen. Liejera, Sankt Petersburg 1885.

Głębocki H., Fatalna sprawa. Kwestia polska w rosyjskiej myśli politycznej (1856-1866), Kraków 2000.

Groniowski K., Dowództwo rosyjskie wobec manifestacji warszawskich 1861 roku, „Przegląd Historyczny" 1961 , t. 52, s. 724-740.

Janowski J.K., Pamiętniki o powstaniu styczniowym, t. 3: Czasy przedpowstaniowe 1854-1862, Warszawa 1931.

Orgelbrand S., Encyklopedia powszechna z ilustracjami i mapami, t. 4: Od litery G do Herburty, Warszawa 1900.

Przed powstaniem styczniowym. Rozprawa w Kole literacko-artystycznym we Lwowie nad ksiażka „Historia dwóch lat 1861-1862” przez Z.L.S., Lwów 1894.

[Przyborowski W.], Historia dwóch lat 1861-1862, t. 1: Część wstępna. 1856-1860, Kraków 1892.

Ramotowska F., Narodziny tajemnego państwa polskiego 1859-1862, Warszawa 1990.

Ramotowska F., Zarząd Wojennego Generat-Gubernatora Warszawskiego, [w:] Archiwum Gtówne Akt Dawnych w Warszawie. Przewodnik po zasobie, red. eadem, t. 2: Epoka porozbiorowa, Warszawa 1998, s. 427-433.

[Stella-Sawicki J.], Ludzie i wypadki z 1861-1865 r., Lwów 1894.

Sziłow D.N., Gosudarstwjennyje dejatjeti rossijskoj imperii. Gtawy wysszich i cjentralnych uczrieżdjenij 1802-1917, Sankt Petersburg 2001.

Szpoper D., Aleksander Wielopolski i próba ustrojowej rekonstrukcji Królestwa Polskiego w latach 1861-1862, [w:] Próba ustrojowej rekonstrukcji Królestwa Polskiego w latach 1861-1862. W 150. rocznicęreform margrabiego Aleksandra Wielopolskiego, red. L. Mażewski, Olsztyn 2012, s. 10-54.

Szpoper D., Pomiędzy caratem a snem o Rzeczypospolitej. Myśl polityczna i dziatalność konserwatystów polskich w guberniach zachodnich Cesarstwa Rosyjskiego w latach 1855-1862, Gdańsk 2003.

Szpoper D., Sukcesorzy Wielkiego Księstwa. Myśl polityczna i dziatalność konserwatystów polskich na ziemiach litewsko-biatoruskich w latach 1904-1939, Gdańsk 1999. 